\title{
Introducing a New Parametric Concept for Land Suitability Assessment
}

\author{
Ahmed H. Rabia and Fabio Terribile
}

\begin{abstract}
In an ecosystem, there is need to establish the quantity and quality of resources and their suitability for a certain range of land uses in order to assure its future productivity and sustainability of biodiversity. Parametric methods are widely used for land suitability evaluation. A new parametric concept "equation" of land suitability evaluation has been proposed to improve results of land suitability evaluation. Land suitability assessment for wheat production was conducted in order to compare results of the suggest method with classical parametric methods. Organic matter, CaCO3, pH, Slope, texture, drainage, depth, EC and altitude were recognized as factors affecting land suitability for wheat production in the study area. Comparing results of the three parametric methods used showed that the proposed equation gave higher suitability index values than classical methods. Great correlation has been found between results of the three methods. Organic matter, topology and $\mathrm{pH}$ were found to be the limiting factors for wheat production in the study area. Generally, the proposed equation may improve land suitability assessment process and gives better realistic results.
\end{abstract}

Index Terms-Land suitability, parametric methods, wheat, pairwise comparison.

\section{INTRODUCTION}

The term "Land suitability assessment" refers to the investigation of a certain part of land's appropriateness to a specific type of land use. This assessment involves many factors that directly or indirectly control the ability of this part of land to host the land use under investigation. Performing land suitability evaluation and generating maps of land suitability for different land use types will facilitate to reach sustainable agriculture [1]. An ecosystem needs an estimation of quantity and quality of its resources and the suitability of these resources for a certain range of land uses in order to assure its future productivity and biodiversity's sustainability [2]. In general, land suitability analysis can answer the questions "which" and "where"; which land use is to apply under certain conditions and where is the best site to apply this land use. Enormous number of studies has been

The manuscript received December 7, 2012; revised January 22, 2013 This work is part of the (LIFE+) project SOILCONS-WEB: Multifunctional Soil Conservation and Land Management through the Development of a Web Based Spatial Decision Supporting System, funded by the European commission.

Ahmed H. Rabia is with University of Naples "Federico II", Faculty of Agriculture, Department of Science of Soil, Plant, Environment and Animal Production. Via Università 100 - 80055 - Portici - Napoli, Italy, also with University of Damanhur, Faculty of Agriculture, Department of Natural Resources and Agricultural Engineering, Damanhur (22511), Elbehera, Egypt. (e-mail: operaharb@htmail.com).

Fabio Terribile is with University of Naples "Federico II", Faculty of Agriculture, Department of Science of Soil, Plant, Environment and Animal Production. Via Università 100 - 80055 - Portici - Napoli, Italy. done to assess the land suitability for different land uses such as different agriculture crops [3]-[6], comparing irrigation systems [7], trees plantation [8], landscape planning and evaluation [9] and environmental impact assessment [10].

Land suitability assessment methods can be divided into relative limitation scale approach (Simple limitation limitation regarding number and intensity) and parametric approach (Storie - square root) [11]. Many researchers have conducted comparison studies between the different land suitability assessment methods [12]-[15]. Although the outcome of the different land suitability methods usually correlated to each other [16], the square root parametric method commonly gives higher results than the storie method. A study was carried out [1] to compare four land suitability methods (Simple limitation, limitation regarding number and intensity, Storie and Square root) and revealed that, square root parametric method is mainly better and more commonly used method in qualitative evaluation. However, it was clear from results that the predicted values were always lower than the observed, which gives the impression that both parametric methods (Storie and Square root) normally underestimates the potentiality of investigated land [1]. The study also recommended that utilizing the outcome of this method in quantitative evaluation gives more realistic results.

Wheat is one of the fundamental food crops and is an essential component in food industry. It has been used in several studies as a reference crop for land productivity evaluation. Of the most important factors that affect wheat production are $\mathrm{CaCO} 3, \mathrm{pH}$, organic matter content, land slope, texture, drainage, soil depth, EC and altitude [1], [16]-[19]. The analytical hierarchy process (AHP), which has been proposed by [20], has been used through a pairwise comparison technique to assign individual parameter's weights for each factor.

This work introduces a new parametric concept, the "Rabia Equation" of land suitability evaluation. Also it compares the results of the proposed method with two classical parametric methods; the Storie and Square root methods. In this study, a land suitability assessment for wheat production was employed in order to compare the final results of the three parametric methods.

\section{MATERIALS AND METHODS}

\section{A. Land Suitability Assessment Methods}

Basically, Land suitability assessment is a multi-criteria problem, as the analysis is a decision/evaluation problem concerning a number of parameters. In general, the land suitability problem can be summarized in a generic model as 
in the following function:

$$
S=f\left(x_{1}, x_{2}, \cdots \cdots, x_{n}\right)
$$

where, $S$ is suitability level and $x_{1}, x_{2}, \ldots, x_{n}$ are the factors affecting land suitability.

Among the different land suitability assessment methods, this work is interested in the parametric methods. The two classical parametric methods (Storie and square root) have been used in comparison with the proposed method (Rabia method). The land suitability parametric approach can be summarized in six steps as shown in Fig. 1, following FAO framework for land evaluation [21] and the procedures proposed by [11].

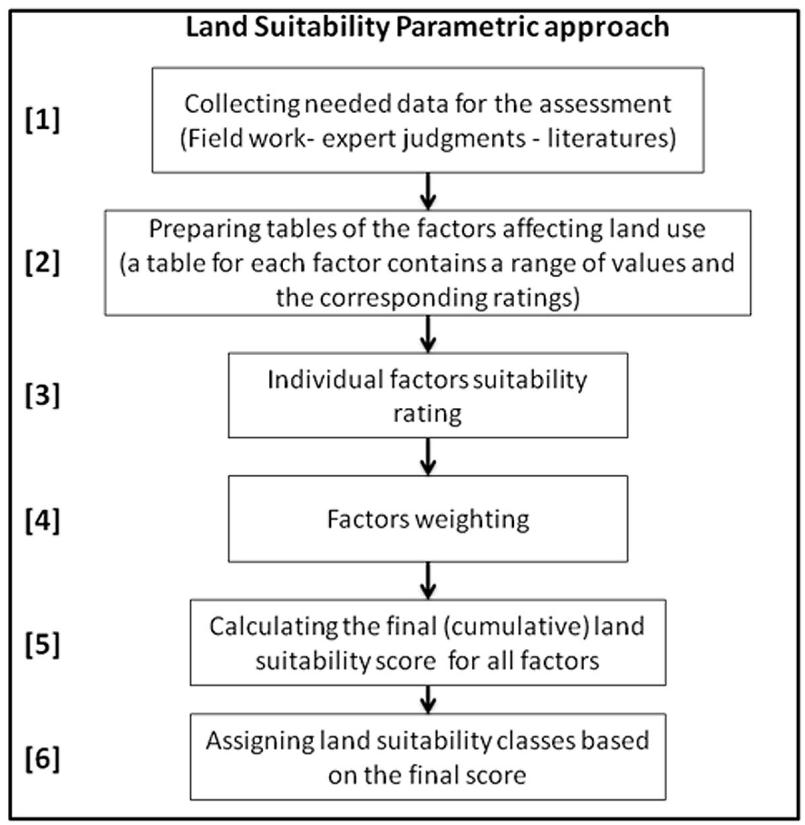

Fig. 1. Flowchart of Parametric approach procedures.

First step of the parametric approach comprise collecting the fieldwork data and judgments from literatures and experts opinions needed for the later evaluation steps. In this stage, the parameters or factors that affect the land use under investigation should be defined. Nine parameters have been named in this work to study land suitability for wheat production. These parameters are organic matter, $\mathrm{CaCO}_{3}, \mathrm{pH}$, drainage, texture, EC, slope, altitude and depth [1], [16]-[19]. In the second step, rating tables for each factor are to be prepared where each table has some values of a factor and the corresponding ratings for these values (usually range from 0 to 100). If the feature is highly suitable, a rating of 100 is to be assigned and if it is not suitable, a minimal rating will be assigned to that feature. In this study the rating tables were adapted from the tables that prepared by Sys et al., [22]. These tables will be used in the third stage to specify ratings for individual parameters in all the sampling sites in the study area. In this step, researchers usually rate the parameters based on the study area situation, experts' suggestions and review of literatures [16].

The following step is to calculate weights for different factors in order to use these weights in the later stages. The analytical hierarchy process (AHP) has been used commonly in Multi Criteria Decision Making (MCDM) or Multi Criteria Evaluation (MCE) [18].

Several studies have documented the (AHP) methodology [23]-[31] and it is not suitable to be portrayed in this study. On the other hand, a number of researches on applications of (AHP) in suitability evaluation have been done [18], [32]-[35]. AHP depends on Pairwise Comparison Matrices to assign weights for every factor controlling the suitability analysis. These matrices compare different parameters to each other and give values (weights) according to their relative importance. These values range from 1 to 9 , where 1 means that the two parameters being compared have the same impact and 9 reveals that one parameter is particularly more important than the other [36]. Finally, the weight of each factor is calculated based on the values given to this factor in comparison to all other factors (Table I).

Finally, land suitability index will be calculated based on ratings of all factors using one of the equations explained later.

TABLE I: PAIRWISE COMPARISON MATRIX OF WHEAT LAND SUITABILITY [20].

\begin{tabular}{|c|c|c|c|c|c|c|c|c|c|c|}
\hline Parameters & $\mathrm{CaCO}_{3}$ & $\begin{array}{l}\text { Organic } \\
\text { Carbon }\end{array}$ & $\mathrm{pH}$ & Texture & Depth & Drainage & $\mathrm{EC}$ & Slope & Altitude & Weights \\
\hline $\mathrm{CaCO} 3$ & 1 & 2 & 3 & 4 & 5 & 6 & 7 & 8 & 9 & 0.2646 \\
\hline Organic Carbon & 0.5000 & 1 & 2 & 3 & 4 & 5 & 6 & 7 & 8 & 0.2135 \\
\hline $\mathrm{pH}$ & 0.3333 & 0.5000 & 1 & 2 & 3 & 4 & 5 & 6 & 7 & 0.1674 \\
\hline Texture & 0.2500 & 0.3333 & 0.5000 & 1 & 2 & 3 & 4 & 5 & 6 & 0.1268 \\
\hline Depth & 0.2000 & 0.2500 & 0.3333 & 0.5000 & 1 & 2 & 3 & 4 & 5 & 0.0919 \\
\hline Drainage & 0.1667 & 0.2000 & 0.2500 & 0.3333 & 0.5000 & 1 & 2 & 3 & 4 & 0.0628 \\
\hline $\mathrm{EC}$ & 0.1429 & 0.1667 & 0.2000 & 0.2500 & 0.3333 & 0.5000 & 1 & 2 & 3 & 0.0396 \\
\hline Slope & 0.1250 & 0.1429 & 0.1667 & 0.2000 & 0.2500 & 0.3333 & 0.5000 & 1 & 2 & 0.0224 \\
\hline Coarse Fragments & 0.1111 & 0.1250 & 0.1429 & 0.1667 & 0.2000 & 0.2500 & 0.3333 & 0.5000 & 1 & 0.0110 \\
\hline
\end{tabular}

Following the procedure proposed by [11] the suitability ratings will be divided into five classes ( $\mathrm{S}$ 1: highly suitable, S2: moderately suitable, S3: marginally suitable, N1 marginally not suitable and N2: permanently unsuitable) and for each suitability class, a range of suitability index is defined in Table II. If an association of two different classes in the same land unit exists, it will be demonstrated by a slash between the simples of the classes (e.g. "S2/N1" means association of classes S2 and N1). 
TABLE II: LAND SUITABILITY CLASSES AND THE CORRESPONDING SUITABILITY INDEX'S RANGES.

\begin{tabular}{cc}
\hline Suitability Class & Suitability index (SI) \\
\hline Class S1: Highly suitable & $>75$ \\
Class S2: Moderately suitable & $50-75$ \\
Class S3: Marginally suitable & $25-50$ \\
Class N1: Marginally not suitable & $10-25$ \\
Class N2: Permanently unsuitable & $<10$ \\
\hline
\end{tabular}

\section{1) Storie method}

$$
S_{i}=A \times \frac{B}{100} \times \frac{C}{100} \times \frac{D}{100} \times \cdots \cdots
$$

where, $S i$ is suitability index, $\mathrm{A}$ is the rating value for texture parameter and $B, C, D$ are the rating values for other parameters.

\section{2) Square root method}

$$
S_{i}=R_{\min } \times \sqrt{\frac{A}{100} \times \frac{B}{100} \times \frac{C}{100} \times \cdots \cdots}
$$

where, $\mathrm{Si}$ is suitability index, $\mathrm{R}_{\min }$ is the minimum rating value of the parameters, and $A, B, C$ are the remaining rating values for other parameters

\section{3) The proposed Rabia method}

The proposed method is a parametric approach developed to enhance the land suitability analysis process and to overcome the limitations of classical methods.

$$
S_{i}=W_{\max } \times \sqrt{\frac{A}{100} \times \frac{B}{100} \times \frac{C}{100} \times \cdots \cdots}
$$

where, $S i$ is suitability index, $W_{\max }$ is the rating value of the parameter that has maximum weight and $A, B, C$ are the remaining Rating values of other parameters.

\section{B. Description of the Study Area}

The study was carried out in an area called Valle Telesina located in Southern Italy, 50 kilometers North-east of the city of Naples, the capital of Campania Region (Fig. 2). Five sub-land systems can be distinguished in the study area, namely: 1) mountains (limestone relieves); 2) alluvial plains; 3) pediment plains (slope fan of limestone reliefs); 4) hills and 5) ancient fluvial terraces. A total of 207 land units were recognized in the study area. The area is characterized by fourteen soil groups (Hapludands, Udivitrands, Eutrudepts, Haplustepts, Calciustepts, Hapludolls, Ustorthents, Melanudands, Ustifluvents, Ustivitrands, Vitraquands, Calciustolls, Hapludolls and Haplustalfs). Climatic conditions are homogenous over the study area and suitable for wheat cultivation. Several land cover and land use types can be distinguished in the study area, including forests, pasture, different types of agriculture and urban settlements. Sixty complete profiles were accomplished to cover the study area and to obtain the edaphological data (Fig. 2).

\section{RESUlTS AND DISCUSSION}

Table III shows land suitability index values and the corresponding classes that have been obtained by the three parametric equations; the Storie, Square root, and the proposed Rabia. The table only shows the first 12 land units and the other parts of the table were omitted for ease of data display. In all the land units of the study area, land suitability index was higher in case of Rabia method than the Storie and Square root methods. It was also observed that the suitability index of Square root method was always higher than that of Storie method [1]. Correlation analysis revealed a high

\begin{tabular}{|c|c|c|c|c|c|c|}
\hline \multirow[t]{2}{*}{ Unit } & \multicolumn{2}{|c|}{ Storie Method } & \multicolumn{2}{|c|}{ Square Root Method } & \multicolumn{2}{|c|}{ Rabia Method } \\
\hline & $\begin{array}{c}\text { Suitability } \\
\text { Index }\end{array}$ & $\begin{array}{c}\text { Suitabili } \\
\text { ty class }\end{array}$ & $\begin{array}{c}\text { Suitabilit } \\
\text { y Index }\end{array}$ & $\begin{array}{c}\text { Suitabilit } \\
\text { y class }\end{array}$ & $\begin{array}{c}\text { Suitabilit } \\
\text { y Index }\end{array}$ & $\begin{array}{c}\text { Suitability } \\
\text { class }\end{array}$ \\
\hline 1 & 30.54 & S3 & 42.81 & S3 & 55.26 & S2 \\
\hline 2 & 13.32 & N1 & 23.09 & N1 & 36.50 & S3 \\
\hline 3 & 28.81 & S3 & 41.58 & S3 & 53.68 & $\mathrm{~S} 2$ \\
\hline 4 & 7.41 & $\mathrm{~N} 2$ & 17.21 & N1 & 25.09 & S3 \\
\hline 5 & 29.75 & S3 & 42.25 & S3 & 54.55 & $\mathrm{~S} 2$ \\
\hline 6 & 9.27 & N2 & 15.22 & N1 & 30.44 & $\mathrm{~S} 3$ \\
\hline 7 & 9.53 & N2 & 19.53 & N1 & 30.87 & S3 \\
\hline 8 & 48.45 & S3 & 53.92 & $\mathrm{~S} 2$ & 69.61 & $\mathrm{~S} 2$ \\
\hline 9 & 40.14 & $\mathrm{~S} 3$ & 49.07 & S3 & 58.41 & $\mathrm{~S} 2$ \\
\hline 10 & 35.01 & S3 & 45.83 & S3 & 54.55 & $\mathrm{~S} 2$ \\
\hline 11 & 72.11 & $\mathrm{~S} 2$ & 78.29 & S1 & 78.29 & $\mathrm{~S} 1$ \\
\hline 12 & 79.31 & $\mathrm{~S} 1$ & 85.65 & $\mathrm{~S} 1$ & 89.05 & S1 \\
\hline
\end{tabular}
correlation between all the three methods (more than 0.95 in all cases).

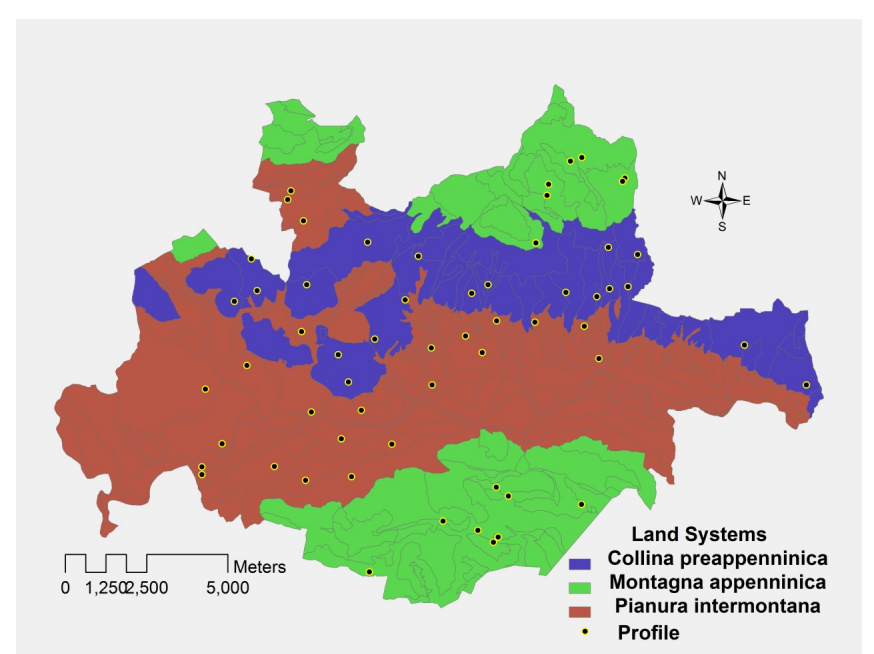

Fig. 2. Land systems of the study area (Valle Telesina) and the distribution of soil profiles.

Regarding land suitability classes, it was clear from results that classes that have been acquired by Rabia method were superior to that of Storie and Square root methods for the same land unit, for example in units 1, 2, 3, 4, 5, 9 and 10. The situation is different in units 6 and 7 where the classification is different in the three methods or as in units 8 and 11 where the land suitability class is the same in both Square root and Rabia methods. In few cases, like in unit 12 , the three methods have produced the same land suitability classification although the suitability index is higher in Rabia method than Square root and the later is higher than Storie methods [37].

This can probably be explained from the observation that in Storie equation, the controlling factor, A simple in 
Equation 2, is directly affected by the other factors in the equation as a result of the multiplication process. While in Square root equation, the limiting factor theory is applied. This limiting factor is the one that has the minimum rating in all factors affecting suitability, Rmin simple in Equation 3, without regarding its weight or impact on the suitability of land use. This may lead, in some cases, to the factor with the minimum rating and controlling the equation result may also have a minimum weight. This possibly leads to a misleading results indicating unreal situation. On the other hand, in the proposed Equation "Rabia method", the controlling factor is the one that has highest weight or impact on the land suitability index value (which is represented by Wmax simple in equation 4). In this way, the equation's final suitability index value was based principally on the factor that has the maximum influence on land use suitability but also with regard to the other factors. So, in the equation used in the "Rabia method", the value of suitability index in addition to the suitability class should be more representative of the real situation, which makes this equation superior to the Storie and Square root equations.

Table IV shows the total area of suitability classes in the three parametric methods. The dominant class with largest area in Storie method is class N1 followed by class N2. While in both Square root and Rabia methods the leading classes were S3 followed by N1. Conversely, the lowest class area was $\mathrm{S} 1$ in Storie method and the association between $\mathrm{S} 2 / \mathrm{N} 2$ in both Square root and Rabia methods. Results showed that applying Rabia method has decreased the total area of the unsuitable classes and increased the area of suitable classes.

TABLE IV: AREA OF LAND SUITABILITY CLASSES FOR WHEAT USING THE Three PARAmetric Methods (Storie, SQuare RoOt, RABia).

\begin{tabular}{cccc}
\hline \multirow{2}{*}{ Suitability Class } & \multicolumn{3}{c}{ Class Area (ha) } \\
\cline { 2 - 4 } & Storie & Square Root & Rabia \\
\hline S1 & 285.96 & 665.72 & 665.72 \\
S1/S2 & 144.43 & 0 & 0 \\
S2 & 1047.97 & 812.65 & 1627.78 \\
S3 & 2039.92 & 7786.96 & 10008.66 \\
S2/S3 & 0 & 873.24 & 1450.56 \\
S2/N1 & 0 & 577.32 & 0 \\
S2/N2 & 0 & 503.86 & 503.86 \\
S3/N1 & 2175.22 & 2135.79 & 1232.67 \\
S3/N2 & 1229.76 & 506.76 & 1008.54 \\
N1 & 5669.01 & 3680.56 & 2352.44 \\
N2 & 5130.29 & 1573.83 & 1275.00 \\
N1/N2 & 2402.66 & 1008.54 & 0 \\
Total Area & 20125.23 & 20125.23 & 20125.23 \\
\hline
\end{tabular}

Fig. 3 shows land suitability maps of the three parametric methods. It illustrates the spatial distribution of the suitability classes over the study area. It can be noticed from the land suitability maps of Square root and Rabia methods that the unsuitable classes (N1, N2 and the associations in between) area concentrated in the North Eastern and Mid-Western parts of the study area while the Southern and Central parts are generally suitable for wheat production. Data analysis has stated also that the limiting factors for wheat production in the study area are organic matter, Topology and $\mathrm{pH}$ [18], [38].

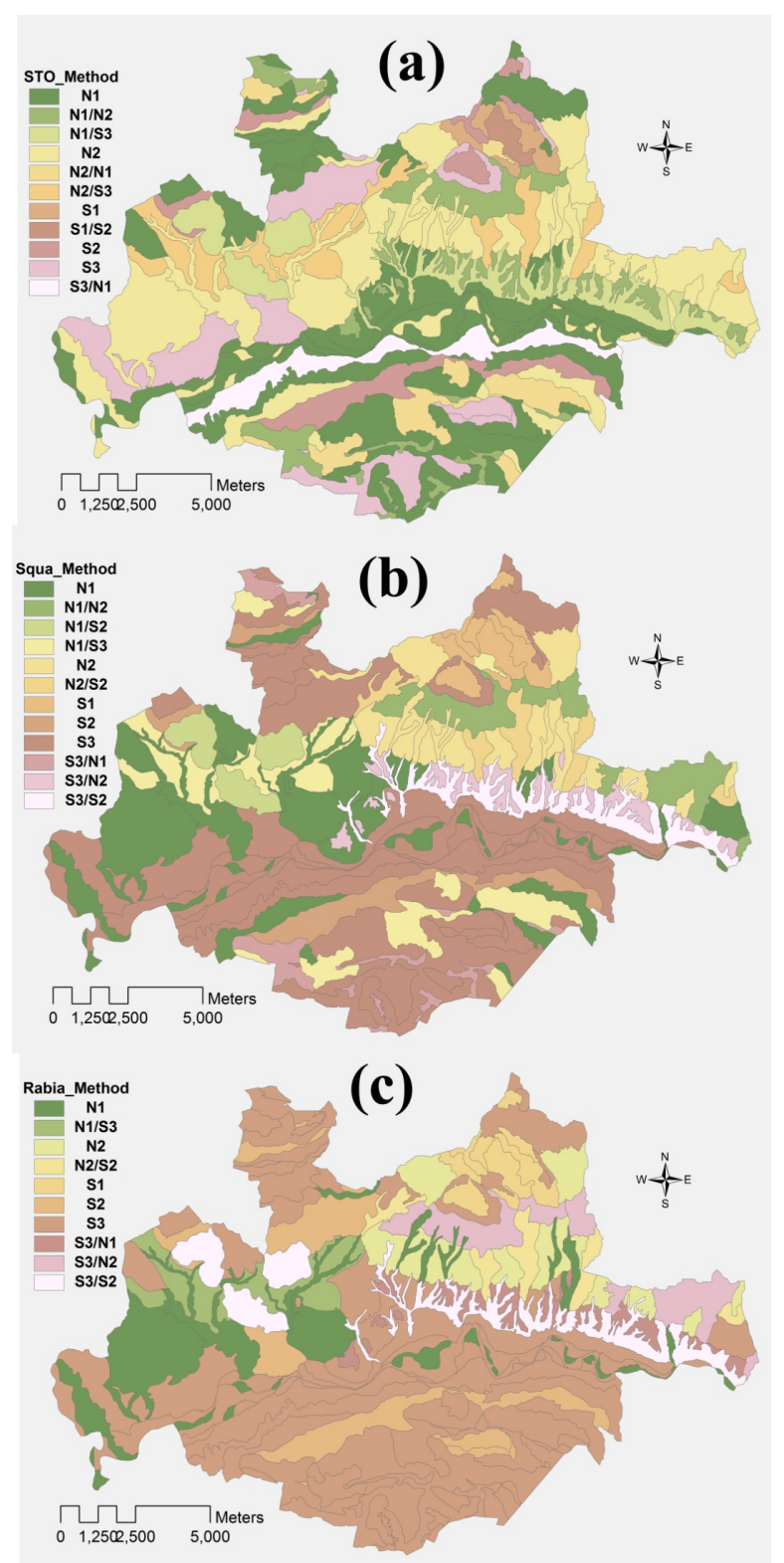

Fig. 3. Wheat land suitability maps for the three parametric methods (a): Storie method, (b): Square root method, and (c): the proposed Rabia method.

\section{CONCLUSION}

Land suitability evaluation is an important process for assessing the value and proficiency of the land and helps in planning for future sustainability of land resources. Accurate assessment methods give better results and consequently facilitate establishment of improved management plans. In this study a new parametric equation has been proposed to improve results of land suitability assessment. Results showed that in all the land units in the study area, land suitability index was higher in case of Rabia method. However, Correlation analysis exposed a high correlation between all the three methods. In addition, the final suitability index value of the equation was based principally on the factor that has the maximum influence on land use suitability with regard to the other factors. As well, results have shown that the limiting factors for wheat production in the study area are organic matter, Topology and $\mathrm{pH}$. In general, results revealed that employing the outcome of this proposed method in quantitative evaluation may give more realistic results. 


\section{ACKNOWLEDGMENT}

The author would like to thank Mr. Collins Okello for his great help during this work.

\section{REFERENCES}

[1] B. Vargahan, F.Shahbazi, and M.Hajrasouli, "Quantitative And Qualitative Land Suitability Evaluation For Maize Cultivation In Ghobadlou Region, Iran," Ozean Journal Of Applied Sciences, vol. 4, no. 1, Issn 1943-2429, 2011.

[2] S. Kilic, F. Evrendilek, S. Senol, and I. Gelik, "Developing a suitability index for land use and agricultural land covers: A case study in Turkey," Environ. Mon and Assess, vol. 102, pp. 323-335, 2005.

[3] H. A. J. Van lanen, M. J. D. Hack - Ten Broeke, J. Bouma, and W. J. M. de Groot, "A mixed qualitative / quantitative physical land evaluation methodology," Geoderma, vol. 55, pp. $37-54,1992$.

[4] A. Jalalian, M. Rostaminia, Sh. Ayoubi and A. M. Amini, "Qualitative, Quantitative and Economic land suitability Evaluation for wheat, Maize and sesame production in Mehran plain, Ilam province Isfahan," university of technology, Agricultural journal, vol. 11, no. 42, pp. 393-403, 2008

[5] B. Y. Zhang, D. zhang, R. E. Ghen, and Y. Li, "A quantitative evalua-tion system of soil productivity for intensive agriculture in china," Geoderma, vol. 123, no. 3, pp. 319 - 331. 2004.

[6] A. H. Rabia, "A GIS based land suitability assessment for agricultural planning in Kilte Awulaelo district, Ethiopia," The 4th International Congress of ECSSS, EUROSOIL 2012 "soil science for the benefit of mankind and environment”, Bari, Italy, pp. 1257, 2-6 June 2012.

[7] A. Landi, S. Boroomand-Nasab, M. Behzad, M. R. Tondrow, M. Albaji, and A. Jazaieri, "Land Suitability Evaluation for Surface, Sprinkle and Drip Irrigation Methods in Fakkeh Plain, Iran," Journal of Applied Sciences, vol. 8, pp. 3646-3653. 2008.

[8] J. C. Menjiver, J. Aquilar, I. Garcia, and p. Bouza, "Evaluation of olive orchard soils of map (Torres, se spain)," International symposium on sustainable use and Management of soil in Arid and semiarid, pp. 984, 2003.

[9] W. Miller, W. M. G. Collins, F. R. Steiner and E. Cook, "An approach for greenway suitability analysis," Landscape and Urban Planning, vol 42, no. 2-4, pp. 91-105, 1998.

[10] D. Moreno and M. Seigel, "A GIS approach for corridor siting and environmental impact analysis," in Proc. GIS/LIS'88. the third annual international conference, San Antonio, Texas vol. 2, pp. 507-514. 1988.

[11] I. Sys, E. Van Ranst, and J. Debaveye, "Land evaluation, part I. Principles in land evaluation and crop production calculations," General administration for development cooperation, Brussels, pp. 40-80, 1991.

[12] L. D. Hopkins, "Methods of generating land suitability maps: A comparative evaluation," J. of American Institute of Planners, vol. 43, no. 4, pp. 386-400, 1977.

[13] L. T. Anderson, "Seven methods for calculating land capability/suitability," Planning Advisory Service (PAS), Report No. 402, Chicago, USA: American Planning Association. 1987.

[14] F. Steiner, "Resource suitability: Methods for analysis," Environmental Management. vol. 7, no. 5, pp. 401-20. 1983.

[15] F. Steiner, "Agricultural land evaluation and site assessment in the United States: An introduction," Environmental Management, vol. 11, no. 3, pp. 375-77, 1987.

[16] S. Ashraf, "Land Suitability Analysis for Wheat Using Multicriteria Evalution and GIS Method," Research Journal of Biological Sciences, vol. 5, pp. 601-605, 2010.

[17] S. Ashraf, R. Munokyan, B. Normohammadan, and A. Babaei, "Qualitative land suitability evaluation for growth of wheat in Northeast of Iran," Res. J. Biol. Sci., vol. 5, pp. 548-552, 2010.

[18] A. A. Mustafa, M. Singh, R. N. Sahoo, N. Ahmed, M. Khanna, A. Sarangi, and A. K. Mishra. "Land Suitability Analysis for Different Crops: A Multi Criteria Decision Making Approach using Remote Sensing and GIS," Researcher; vol. 3, no. 12, pp. 61-84, 2011.

[19] M. Mokarram, K. Rangzan, A. Moezzi, and J. Baninemeh, "Land Suitability Evaluation for Wheat Cultivation by Fuzzy Theory Approach As Compared With Parametric Method" The International Archives of the Photogrammetry, Remote Sensing and Spatial Information Sciences, vol. 38, Part II. 2010.

[20] T. L. Saaty, "A scaling method for priorities in hierarchical structures," J Math Psychol, vol. 15, pp. 234-281. 1977.

[21] FAO, "A framework for land evaluation," Soils Bulletin 32. FAO, Roma. pp. 72, 1976.
[22] C. Sys, V. Ranst, J. Debaveye, and F. Beernaert. "Land Evaluation Part III, crop requirements," Agr publication No. 7, ITC Ghent. 1993.

[23] G. A. Mendoza and W. Sprouse. "Forest planning and decision making under fuzzy environments: An overview and analysis," Forest Science, vol. 35 , no. 2, pp. 481-502, 1989.

[24] G. A. Mendoza, "Introduction to Analytic Hierarchy process: Theory and applications to Natural Resources Management," In Proceedings of 1997 ACSM/ASPRS Annual Convention. Resource Technology. Seattle, WA. vol 4.pp.130-39. 7-10 April 1997.

[25] T. L. Saaty, "The Analytic Hierarchy Process," New York: McGraw-Hill. International,Translated to Russian, Portuguese, and Chinese, Revised editions, Paperback (1996, 2000), Pittsburgh: RWS Publications. 1980.

[26] T. L. Saaty, "Decision making for leaders: The analytic hierarchy process for decisions in a complex world," RWS Publication, PA. 3rd Edition. 1995.

[27] J. Kangas, "Multiple-use planning of forest resources by using the Analytic Hierarchy Process," Scand. J. of For. Research, vol. 7, pp. 259-68. 1992.

[28] J. Kangas, "A multi-attribute preference model for evaluating the reforestation alternatives of a forest stands," Forest Ecology and Management, vol. 59, pp. 271-88. 1993.

[29] D. L. Peterson, D. Silsbee, and D. L. Schmoldt, "A case study of resource management planning with multiple objectives," Environmental Management. vol. 18, no. 5, pp. 729-42, 1994.

[30] K. M. Reynolds and E. Holsten. "Relative importance of risk factors for spruce beetle outbreaks," Can. J. of For. Research. vol. 24, no. 19, pp. 2089-2095, 1994

[31] T. Pukkala and J. Kangas, "A method of integrating risk and attitude toward risk into forest planning," Forest Science, vol. 42, no. 2, pp. 198-205, 1996.

[32] R. Banai-Kashani, "A new method for site suitability analysis: The analytic hierarchy process," Journal of Environmental Management vol. 13 , no. 6 , pp. 685-693, 1989.

[33] J. R. Eastman, W. Jin, P. Kyem, and J. Toledano. "Participatory procedures for multi-criteria evaluations in GIS," Proceedings, in EGIS'92, pp. 281-88. Buffalo, N.Y. 1992.

[34] J. R. Eastman, P. Kyem, and J. Toledano. "A procedure for multi-objective decision making in GIS under conditions of multiple objectives," Proceedings, EGIS'93, pp. 438-47. 1993.

[35] W. Xiang and D. L. Whitley. "Weighting land suitability factors by the PLUS Method," Environment and Planning B: Planning and Design vol. 21, pp. 273-304. 1994.

[36] T. L. Saaty and L. G. Vargas, "Models, methods, concepts, and applications of the analytic hierarchy process," Boston etc., Kluwer Academic, pp. 327, 2001

[37] S. Khordebin and A. Landi, "Comparison of the Land Qualitative Suitability with the Use of FAO Method and Ales Model for Major Crops in Sardasht of Behbahan Khuzestan Province, Iran," Middle-East Journal of Scientific Research vol. 10, no. 4, pp. 477-481, 2011.

[38] A. Rezaei, M. Farboodi, and M. H. Masihabadi. "Land suitability survey and different planting dates for farming of burley 21 tobacco in Marivan," $19^{\text {th }}$ World Congress of Soil Science, Soil Solutions for a Changing World, August 2010.

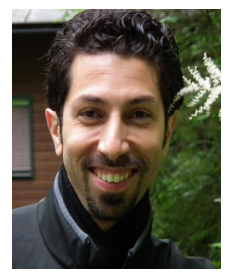

A. H. Rabia is an assistant lecturer at Faculty of Agriculture, University of Damanhur, Egypt. He holds a Master's Degree Course in Geomatics and Natural Resources Evaluation from Faculty of Agriculture, Firenze University, Italy, a Master's degree in Soil and Water science from Alexandria University (2007) and Bachelor of Science from Faculty of Agriculture, Alexandria University (2001). He is currently a PhD scholar at university of Naples "Federico II", Italy. His $\mathrm{PhD}$ is about improvement and management of agricultural resources and forests.

His main fields of scientific interests include soil science, GIS and remote sensing, Impacts of Climate change on soils, land use change and climate change modeling.

Dr. Rabia is a member of many professional societies such as the Italian Society for Soil Science SISS, the International Geospatial Society, the Global Spatial Data Infrastructure Association, the Egyptian Society for Soil Sciences, Prof. Dr. A. M. Balba Society for Soil and Water Research, Journal of Agricultural and Environmental Sciences, Alexandria Science Exchange Journal. 